\title{
INDIGENOUS LIBRARIANSHIP
}

This article was originally published in 2009.

Burns, Kathleen, Doyle, Ann, Joseph, Gene, \& Krebs, Allison. (2009). Indigenous librarianship. In M. J. Bates, \& M.N. Maack (Eds.), Encyclopedia of library and information sciences $\left(3^{\text {rd }}\right.$ ed.). Boca Raton, FL: Taylor \& Francis.

Online: http://www.tandfonline.com/doi/book/10.1081/E-ELIS3

Print: http://www.crcpress.com/product/isbn/9780849397127

\section{CONTENTS}

\author{
Abstract \\ Keywords \\ Introduction \\ Methodology \\ Terminology \\ INDIGENOUS PEOPLES AND LIBRARIES \\ United States \\ Profile: Lotsee Patterson \\ Canada \\ Profile: Thawennersere / Charles Angus Cook \\ Australia \\ Profile: Joe Neparrya Gumbala \\ Aotearoa/New Zealand \\ Profile: Chris Szekely \\ Indigenous Libraries and Their Intersections \\ Profile: Gene Joseph \\ KEY ISSUES IN INDIGENOUS LIBRARIANSHIP \\ Indigenous Libraries \\ The digital divide \\ Profile: Jean Whitehorse \\ Universal Access: An Elusive Principle \\ Indigenous Approaches to Literacy \\ Profile: Loriene Roy \\ Indigenous knowledge organization \\ Indigenous cultural and intellectual property \\ Indigenous Protocols for Libraries \\ Virtual Repatriation \\ RESEARCH IN INDIGENOUS LIBRARIANSHIP \\ EDUCATION FOR INDIGENOUS LIBRARIANSHIP \\ PROFESSIONAL ASSOCIATIONS \\ CONCLUSION \\ Acknowledgements \\ Authors \\ REFERENCES
}




\begin{abstract}
Indigenous librarianship unites the discipline of librarianship with Indigenous approaches to knowledge, theory, and research methodology. It has a developing bibliography and local, national and international professional associations devoted to its growth. A focus of Indigenous librarianship is the provision of culturally relevant library and information collections and services by, for and with Indigenous people. Grounded in the contemporary realities of Indigenous people and Indigenous aspirations for self-governance and sovereignty, it has a critical theoretical base. Its practice may be carried out in places ranging from small Indigenous community libraries to specialized collections in large research institutions. As an emergent scholarship the field is in the process of defining itself. This article serves as an introductory overview to the history, practice, issues, and theoretical approaches associated with Indigenous librarianship.
\end{abstract}

\title{
KEYWORDS
}

Indigenous librarianship * Indigenous information studies * Indigenous research methodology * Tribal libraries * First Nations libraries * Indigenous knowledge organization * Library and information services for Indigenous people * Intercultural librarianship * Delgamuukw librarian * Aboriginal rights and title claims research and libraries * Virtual repatriation * Digital divide

\section{INTRODUCTION}

Indigenous librarianship unites the discipline of librarianship with Indigenous approaches to knowledge, theory, and methodology. It emerged as a distinct field of practice and an arena for international scholarship in the late $20^{\text {th }}$ century bolstered by a global recognition of the value and vulnerability of Indigenous knowledge systems, and of the right of Indigenous peoples to control them. (1-2) Its growth converges with the development of Indigenous research paradigms that place Indigenous control, benefit, and values at the center of research. (3) The field of Indigenous librarianship is rooted in long-standing and established practices that Indigenous peoples employ to create, transmit and preserve knowledge. These practices maintain Indigenous cultural and social systems and provide protocols for ownership and the appropriate use of community knowledge. (4-5)

Indigenous librarianship has a developing bibliography and local, national and 
international professional associations devoted to its growth. (6) Its foundations rest on strong understandings of the concerns of Indigenous people about the intersections between Indigenous knowledge and culture, and library and information science. Indigenous cultural principles are considered critical to restoring and continuing the principles of Indigenous knowledge management and sharing. Indigenous librarianship encourages the broader profession to move beyond its own disciplinary knowledge base and engage in multidisciplinary approaches with Indigenous cultural experts, information technology developers, governments and other institutions. (7)

The article offers a survey of this emergent field through describing its social and historical contexts, profiling some leading practitioners, and highlighting some key issues. The geographic focus on the United States and Canada is contextualized by Indigenous practice in Aotearoa/New Zealand and Australia, and reference to other international initiatives in order to give a sense of the breadth and diversity of the field. Key issues identified in the article include the development of Indigenous libraries, Indigenous people's access to public collections and public institutions, Indigenous approaches to literacy, Indigenous knowledge organization, Indigenous cultural and intellectual property considerations, and virtual repatriation. The key issues section is followed by a possible future research agenda in Indigenous librarianship, as well as, a call for curriculum development within the field for tribal librarians and librarians in public institutions. The article then overviews some professional associations led by Indigenous information professionals. As an emergent scholarship, the parameters and scope of Indigenous librarianship are fluid and although it enjoys an international discourse there is as yet no codified definition of the field. This article therefore describes some of its salient features and one approach to mapping the landscape of Indigenous librarianship.

\section{Methodology}

The reality of the practice of Indigenous librarianship is under reported and exists beyond the literature: it exists in the lives of those who work directly with Indigenous peoples. (8) Indigenous library workers are "local heroes" who serve as a link between the past and present generations. They often work outside of the mainstream and in Indigenous cultural and collecting institutions that are outside of state or public systems. (9) This article incorporates a 
biographical approach in order to acknowledge the achievements of Indigenous librarians and library workers. The approach is informed by Indigenous research methodologies that aim to surface the contributions of Indigenous people, and aligns with Linda Tuhiwai Smith's Indigenous projects of testimony, storytelling, sharing, and returning. (10)

\section{Terminology}

The original inhabitants of North and South America, Australasia, Africa and Asia are often identified as a type of collectivity that is seen in contradistinction to the Western or dominant society. Terminology that represents this collectivity includes words such as tribal, Native, Aboriginal, and Indigenous. The original inhabitants within any specific country are culturally and linguistically diverse although they may also be classified as a single group within their countries. The terminology used by the state often reflects a classification established by the force of law within a country and imposes external concepts of identity that may or may not be accepted by Indigenous individuals or collectives. This is a complex area with its own literatures and discourses where meanings are constructed in legal, social, cultural and political contexts. (11) In addition to specific names of nations, communities, cultural and language groups, there are various generic terms used to denote Indigenous peoples.

In Canada the term Aboriginal is defined under Section 35 of the Constitution Act (1982) as including Indian, Métis, and Inuit peoples. For the purposes of this article it is used more broadly to include all First Nations, status and non-status Indians, Métis and Inuit people. The term First Nations arose in the 1970s to replace the word Indian, which is sometimes considered offensive, and refers to a body of Aboriginal people with a shared national identity. First Nations is also used to replace the word band, a term defined by the Indian Act to mean a body of people defined as Indian by the government. A status Indian is a person who is registered as an Indian under the Indian Act; conversely a non-status Indian is a person not registered as an Indian under the Indian Act. Métis people are of mixed First Nations or Inuit and European or other ancestry who may also identify as a nation, often the Métis Nation within Western Canada. (12)

Within the United States the collective term Native American may include, American Indian, Alaska Native, and Native Hawaiian. In Canada, the United States, Australia and New Zealand, Indigenous people claim the right to define their own cultural identity and membership 
and may not accept the definitions of the state. Within international arenas, the term Indigenous peoples is pluralized to denote the great diversity among Indigenous groups at the same time as it serves as a collective term. Indigenous peoples are seen to be "the inheritors and practitioners of unique living cultures and ways of relating to other people and to the environment who have retained social, cultural, economic and political characteristics that are distinct from those of the dominant societies in which they live." (13)

\section{INDIGENOUS PEOPLES AND LIBRARIES}

The United Nations estimates that there are 4,000 to 5,000 Indigenous cultures, with over 370 million individuals belonging to these cultures in more than 70 countries globally. (14) The cultural and linguistic diversity among Indigenous peoples belies a shared experience of historic and ongoing colonialism: Indigenous peoples globally continue to face the ongoing effects of dispossession of lands, languages, cultures and knowledge. Many Indigenous people face economic barriers, lack access to education and social services, and regularly deal with racial discrimination. Consequently, Indigenous people often share similar concerns related to the protection of rights, lands, resources, and cultural and intellectual property, and struggle to gain social equity. From the perspective of information studies, Lynette Russell, Director of Monash University's Centre for Australian Indigenous Studies observes, “The First peoples in Aotearoa/New Zealand, Canada, the United States of America along with many other Indigenous peoples face similar issues relating to access to, and control of, information about their cultures and communities." (15)

\section{United States}

The United States 2000 census figures show 4.1 million American Indians and Alaska Natives who comprise $1.5 \%$ of the total population. (16) Approximately one-third live on one of 300 reservations with the remainder living in urban and rural areas. The population is young in comparison with the general population. One third of the population lives below the poverty line, experiencing lower high school graduation rates, and less presence in higher education. (17) There are 175 Indigenous languages spoken in the United States however, 55 are spoken by 
fewer than 10 people; 70 are spoken only by Elders; and only 50 of them are spoken by two or more generations. As in other countries, Indigenous language loss is considered a key factor in cultural erosion, and Native language maintenance and revitalization are a high priority. (18)

The relationship between Native Americans in the United States and librarianship is fundamentally different from that of other cultural groups because tribal nations have a formal relationship with the federal government. This relationship is set out in treaties and court decisions intended to assure tribes with access to services related to health, education and general welfare. (19) Although education is a treaty right of Native Americans, and access to libraries and information is integral to the education process, library services to people living on reservations did not begin to become available until the 1970s. (20) During the 1970s, a convergence of changes in federal legislation, court decisions, and increased receptivity to American Indian self-determination efforts, enabled tribal libraries to slowly begin to develop. The National Commission on Libraries and Information Science (NCLIS) hearings in 1974, examined library services to urban and on-reserve American Indians and identified a great need for LIS services and an 'abysmal' lack of formal policy. The White House Pre-Conference on Indian Library and Information Services On or Near Reservations (1978) gathered representatives from 103 tribes to lay the groundwork to improve library services for American Indians and shape U.S. Federal library and information policy. The tribal representatives advocated for tribal libraries as spaces to foster and preserve cultural heritage for future generations, and became a keystone in this national library service framework. Tribal libraries can strengthen oral traditions through preservation programs and the dissemination offered by print as well as new media. They serve the educational, informational and recreational interests of Native Americans, as well as provide vital access to government data that supports selfgovernance activities.

Despite Native American aspirations for library services expressed through these gatherings, over twenty years later the NCLIS report Pathways to Excellence: A Report on Improving Library and Information Services to Native American Peoples (1992) again documented inadequate library services for Native Americans characterized by discrimination and lack of culturally appropriate services for off-reserve populations, and geographic barriers to access on-reserve. (21) Ten challenges facing tribal library development included: consistent funding at federal, state, local, and tribal government levels; training and technical support for 
Native American communities; relevant collection development; improved access; state and local partnerships; identification of model programs; the expansion of the tribal library program to include museum and archival services; support for literacy and job skills training; support for IT; and the establishment of federal responsibilities.

Currently, support of tribal libraries crosses multiple jurisdictional boundaries: tribal, local, county, state, regional and federal. Each represents potential revenue streams to advance tribal library sustainability. Within the library sector, at the federal level, the Institute for Museum and Library Services (IMLS) offers basic non-competitive grants for local tribal libraries as well as funds for innovative projects within tribal libraries. It offers national leadership initiatives designed to foster collaborative efforts and develop best practices, and funding for diversity scholarship program initiatives such as Knowledge River at the University of Arizona and Honoring Generations at the University of Texas, Austin. At the state level, some examples of initiatives are found in Arizona, New Mexico, Montana, and Oklahoma. The Arizona Gathering of Tribal Librarians is currently planning its seventh Gathering for the Spring of 2008, and a Tribal Library Consultant is employed within the Arizona State Library, Archives and Public Records. The New Mexico State Library's Tribal Libraries Program (TLP) includes the TLP Direct non-competitive grant for tribal libraries (22) and the Indigenous Nations Library Program (INLP) at the University of New Mexico. (23) In Montana, the Tribal College Librarians Professional Development Institute has been held annually since 1990 at Montana State University in Bozeman. (24)

The Tribal Archives, Libraries and Museums (TALM) conferences held bi-annually since 2003 are excellent examples of cross-jurisdictional collaboration. Originating from an IMLS National Leadership Grant awarded in Arizona in 2003 and 2005, the concept was expanded through an IMLS Laura Bush Librarians for the twenty-first Century Grant to the Western Council of State Libraries for 2007-2009. The Oklahoma Department of Libraries hosted the 2007 National Tribal Archives, Libraries and Museums (TALM) conference. Four National Immersion Institutes followed in 2008, one each focusing on Archives, Caring for Native American objects, Photographic Preservation, and Tribal libraries. The final conference of this grant cycle will be hosted by the Oregon State Library and Tamástslikt Cultural Institute in Oregon in 2009. (25) The ability to create platforms for collaboration and professional exchange facilitates the development, definition, and vitality of the emergent field of practice 
and study. They provide opportunities to discuss issues relevant to Indigenous communities, meet other practitioners, and allow Indigenous librarians to center their practice within Indigenous ways of knowing. Coupled with training institutes these types of initiatives support the development of Indigenous library workers and information professionals, envisioned through the leadership of Indigenous librarians. (Fig. 1)

\section{Fig. 1 Profile: Lotsee Patterson}

Dr. Lotsee Patterson, an enrolled member of the Comanche Nation raised on her mother's allotment in southwestern Oklahoma, is Professor Emeritus at the University of Oklahoma School of Library and Information Studies. Dr. Patterson is a founder and past-president of the American Indian Library Association. She is a well-known lobbyist for national legislation to fund and improve library services to United States tribes, and for helping to establish tribal libraries in the United States. Beginning in the early 1970s, Dr. Patterson wrote successful grant applications to hold training institutes for American Indian library aides, believing that training staff would pave the way for tribal libraries. Patterson carried out a series of groundbreaking tribal library demonstration projects in the 1970s, eventually publishing the seminal TRAILS (Training and Assistance for Indian Library Services) manual in 1984, a key resource for tribal librarians. Dr. Patterson co-chaired both the 1979 and 1991 Native American pre-conferences to the White House Conference on Library and Information Services, and has mentored hundreds of American Indian librarians and students throughout her career while persistently spotlighting the critical need to fund tribal libraries and commit resources to library services for American Indians. In 2005, Dr. Patterson was recognized as "one of the most outspoken advocates for equitable library services for American Indians" with an honorary ALA membership award for her outstanding and lasting contributions to the field of librarianship. (26-27)

\section{Canada}

In Canada the Aboriginal population is young and growing. It has increased by $45 \%$ in the past decade and is estimated at 1 million. The increase may be attributed to a variety of factors including tendency to self identify, birth rate, and legislative changes to definitions. By 2017 Aboriginal young adults (aged 20-29) are expected to compose one-third of the young adult population in the province of Saskatchewan; 24\% in Manitoba; $40 \%$ in the Yukon 
Territory and 58\% in the Northwest Territories. (28) Currently the Aboriginal population is comprised of approximately 60\% First Nations people, 33\% Métis people, and $4 \%$ Inuit who live primarily in the Arctic regions. Over half of the Aboriginal population lives in urban areas. In Canada there are 615 First Nations, 10 unique language families and over 60 different Aboriginal languages spoken in the country although, many Aboriginal languages in Canada are endangered and many have been lost. The Indian residential school system operating (variously across the country) from the $19^{\text {th }}$ century to the 1990 s resulted in the dislocation of Aboriginal families and communities, the disruption of cultures and cultural transmission, and the near eradication of some Aboriginal languages. As a consequence cultural and language revitalization and self-determination efforts among First Nations and Aboriginal communities are of high importance. The ongoing intergenerational impacts of the residential school system, and colonization in general, continue to be felt today. (30) On June 11, 2008, the Prime Minister of Canada and the Federal party leaders issued an official apology to the Aboriginal people of Canada for the damage and suffering caused by the assimilationist policies of the Canadian government. (31) The courage and resilience of Aboriginal people and the strengths of Aboriginal cultures were acknowledged, and a Truth and Reconciliation commission established to foster reconciliation between Aboriginal people and all Canadians and rectify the public historic record.

Public library services for Aboriginal people in Canada are uneven across the country. In some provinces jurisdictional issues are cited as rationale for the lack of free access to the public library system for Aboriginal people. Because First Nations and Métis people may be considered a federal jurisdiction and public libraries tend to be funded at municipal or regional levels, the principle of universal access to public libraries does not extend in practice for Aboriginal people. In British Columbia (B.C.), there are no public libraries on reserve, and the libraries that do exist on reserve are generally small, underfunded band council collections, and band school libraries. $(32,33)$ In Ontario, although the provincial government contributes to the development of public libraries in First Nations communities, in 2001-2002, only 52 of 141 First Nation libraries in Ontario received operating grants, and because these grants are based on population size many small communities are underfunded. (34) Among First Nations communities, the development of local tribal libraries may not be a priority when efforts are focused on rights and title claims, health, social, economic, and educational infrastructure. A 
First Nations library worker explains: "We need all our money to fund our land claims. If we don't have land, we don't have community. If we don't have community, we don't need a library." (35)

The province of Saskatchewan is among the leaders in developing equitable, culturally relevant Aboriginal public library and information services in Canada. The Saskatchewan Minister's Advisory Committee on Library Service for Aboriginal people report, Information is for Everyone (2001), makes 46 recommendations for improved library and information services for Aboriginal people. It highlights universal access to library services for all Aboriginal people including on-reserve and off-reserve; collaborative partnerships for equitable access; and public education about Aboriginal issues. The Library Services for Saskatchewan's Aboriginal Peoples Committee is composed of Aboriginal and public sector representatives who meet six times a year to advise on the implementation of the recommendations. (36) A key principle, similar to repeated earlier ones in Ontario service reviews, is First Nations control of on-reserve library services and of the development of on-reserve library services.

Public libraries in urban centres tend not to differentiate between Aboriginal people and the general population. As a consequence urban Aboriginal populations are often not well served. There are exceptions, such as the Albert Library branch of the Regina Public Library (37) and the Spadina branch of the Toronto Public Library that each work closely with local urban Aboriginal communities. The Edmonton Public Library conducted a survey in order to improve Aboriginal library services in Edmonton. The final report, Library Services to Aboriginal Peoples: Task Force Report (2005), includes an environmental scan with recommendations. (38)

At the national level, a Library and Archives Canada national consultation on Aboriginal library services in 2003 resulted in a report that included 10 focus areas for improvement including: consultation and partnerships; funding and resources; jurisdiction; planning and administration; universal and equitable access; education and training; advocacy; promotion; authenticity of voice; outreach and networking (Fig. 2). (39) 


\section{Fig. 2 Profile: Charles Angus Cook (Thawennersere (1870-1958)}

The tenacity and vision of Charles Angus Cook (Thawennensere or Da-ha-wen-nen-se-re), a Kanesatake Mohawk, set a standard for the aspirations of Aboriginal library services in Canada. Da-ha-wen-nen-se-re (Charles Cook) worked for the Canadian Indian Affairs Records Branch from 1893-1926 as a clerk who classified documents relating to Indians in Canada, and as a translator who translated Iroquois dialects into English. Early in his career he envisioned and advocated for a National Indian Library. He lobbied tirelessly for the development and proper organization of the Department of Indian Affairs' collection of Indian materials, and recommended supplementing the government's collection with materials contributed by Aboriginal people in order to reflect Aboriginal perspectives and interests. He recommended free access to the collections for departmental staff and for all status Indians. In later years, Daha-wen-nen-se compiled a Mohawk dictionary and published a Mohawk language newspaper, Onkweonwe, the first newspaper in Canada to be produced and published by an Aboriginal publisher. (40)

\section{Australia}

The Indigenous people of Australia compose two culturally distinct populations: the Aboriginal Australians and the Torres Strait Islander people. The Torres Strait Islander people traditionally inhabit the Torres Strait Islands north of Cape York, Queensland. The Australian Aboriginal people live primarily in mainland Australia, including Tasmania. In 2006, 2.5\% of Australia's total population of over 21 million identify as Indigenous. The Indigenous population is also young and growing rapidly with 39 percent of the population under 15 years of age. While the largest proportion of Indigenous people live in urban areas (30\%), a high proportion live in the Outer Regional (23\%), Remote (9\%), and Very Remote (18\%) areas. (4142)

Before European contact, Indigenous peoples in Australia comprised over 500 language groups. Beginning in the late 1700 s, British colonization violently suppressed Aboriginal cultures: colonial legislation regulated segregation, restricted movement, and forcibly removed children from their families resulting in cultural disruption and damaged the wide diversity and 
strength of Indigenous peoples and cultures. (43) The Australian government's report, Bringing Them Home (1997), documented the impact of over 150 years of these policies that dislocated families, impacted physical and mental health, resulted in disruption of language, culture and connection to traditional lands. On February 13, 2008, a historic parliamentary vote adopted Prime Minister Kevin Rudd's apology on behalf of all Australians for the harm done to the Indigenous people of Australia. (44).

A 1993 report revealed that Australian Indigenous library services relied on erratic grant funding and were usually initiated by community or educational organizations. (45) A year later, an Indigenous Advisory Committee was established to assist with the development of equitable access and services. The Library and Information Service of Western Australia (LISWA) generated a number of Indigenous-focused service plans aimed at improvement, including Public Libraries: Good Places for Aboriginal People (1995) and Services to Aboriginal and Torres Strait Island Peoples (1997).

The State Library of Queensland, acknowledging that Indigenous Australians were “denied, excluded, and/or discouraged access" implemented an Indigenous Library Services Strategy in 2002 focusing on the establishment of Indigenous Knowledge Centres (IKCs), improving public library services for Indigenous Australians, raising the profile of Indigenous people in libraries, particularly at the State Library, and increasing Indigenous employment and training opportunities. (46) By 2008, partnerships between Indigenous communities, local governments, and the State Library of Queensland resulted in the creation of 17 Indigenous Knowledge Centres (IKC) that are owned and managed by each community. An IKC is a community space that offers traditional library services and can be located in community keeping places, small museums or other locales. Currently, in addition to initial set-up costs, the State Library of Queensland provides training and development programs to facilitate the preservation and sharing of local Indigenous knowledge, orally and digitally, as well as access to Australian Indigenous cultural materials held in collecting institutions throughout the world. The first Indigenous Knowledge Centre in a State Library, kuril dhagun, is located in the Queensland State Library. A literal translation of the name is 'kuril's place': kuril is the marsupial native to the area, and dhagun means earth/place/country. It serves as a meeting place for Indigenous people and a welcoming space for all Australians to engage with traditional and contemporary expressions of Queensland Indigenous knowledge. (46a) The Queensland State 
Library has developed its own policies on reconciliation, cultural protocols, language preservation and maintenance, public library services, and employment and training in the library and information sector. The Library has been instrumental in the development of the National Policy Framework for Aboriginal and Torres Strait Islander Library Services and Collections (47-48) which was replaced in 2014 with the National Position Statement for Aboriginal and Torres Strait Islander Library Services and Collections. (46-49)

In 2006, an evaluation of the Northern Territory's Libraries and Knowledge Centres (LKCs) model led by Dr. Martin Nakata, a Torres Strait Islander, and Director of Indigenous Academic Programs at Jumbunna Indigenous House of Learning, University of Technology Sydney, concluded that the model had the potential for extension across the Northern Territory. (50) The model incorporates Indigenous knowledge as part of a community-centered information and knowledge base to support the goals of community-building through libraries, and the provision of sustainable public library services that are relevant to multi-lingual, clanbased, Indigenous communities. Indigenous knowledge centres are also being developed in Africa, Latin America and Asia to revitalize endangered cultures and languages, contribute to economic development, and centre Indigenous planning and development (Fig. 3). (51)

\section{Fig. 3 Profile: Joe Neparrya Gumbala}

Joe Neparrya Gumbala, a Gupapuyngu Yolyu Elder and musician from North East Arnhem Land, is a leading authority on Yolyu intellectual and legal traditions. Gumbala is widely respected for his depth of Yolyu knowledge and his ability to interpret other knowledge systems using Yolyu frames of reference. (52) In his role as a Community Liaison Officer at the Galiwin'ku Indigenous Knowledge Centre (IKC) in northeast Arnhem Land, Gumbala travels throughout Australia locating collections of Yolyu family histories and other cultural heritage materials, and returning digital copies to Gupapuyngu communities for local access. Gumbala applies Yolyu knowledge organization systems to the management of the knowledge centre's digital collections. Yolyu knowledge, ceremony and law have three strata — restricted, perirestricted, and public. All Yolyu materials are bound by these access and ownership principles. Kinship relations define related secondary rights to intellectual and physical property, and determine access to both historic and contemporary Yolyu materials at the Galiwin'ku IKC. (53) 


\section{Aotearoa/New Zealand}

The Māori people are tangata whenua "people of the land" or Indigenous peoples of New Zealand. The Māori word tangata translates as the land and those who hold spiritual authority in a particular place due to a deep and ancestral relationship it. The traditional land of the Māori is Aotearoa, Land of the Long White Cloud (53a). In Aotearoa/New Zealand, Māori people represent about $15 \%$ of the population and are expected to reach $21 \%$ by the year 2051 . Like many Indigenous people, the Māori are increasingly urbanized, and face social and economic inequities that result in comparatively high unemployment, incarceration, and mortality rates, and lower outcomes in educational achievement, health, and income. (54)

During the early colonization period, Māori people adopted the orthography of the missionaries and produced a significant body of manuscript and printed materials written in the Māori language that is now held in public collections. In 1840 the Treaty of Waitangi was signed by over 500 chiefs in order to guarantee ongoing Māori ownership of lands, fisheries and other possessions and grant full British citizenship to Māori people. However, ongoing infringements of the Treaty of Waitangi provisions resulted in the establishment a permanent commission of enquiry, the Waitangi Tribunal, in 1975 to provide a mechanism for contesting breaches of Treaty promises and agreements. Evidence used in support of Waitangi treaty claims frequently relies on documentary materials held in libraries and archives throughout Aotearora/New Zealand that may be written in the Māori language and/or in English. Māori access to library and archive holdings is therefore central to the ongoing settlement of Māori claims and to the national reconciliation process. These collections also support Māori efforts to revitalize language and culture disrupted through colonization processes. This socio-legal context sets the stage for Indigenous librarianship in Aotearoa/New Zealand and for understanding the key importance of the development of the Ngā Ūpoko Tukutuku/Māori subject heading thesaurus and its role in the provision of access to Māori collections for and by Māori people.

Beginning in the 1990s the Library and Information Association of New Zealand Aotearoa (LIANZA) initiated a national research project on biculturalism issues and services to Māori, Te Ara Tika (translated as 'the right path'). The first phase undertook as analysis from the perspective of the library profession; the next phase surveyed Māori information needs and 
Māori opinion about libraries and library services. The findings are documented in Te Ara Tika Guiding Voices report (1997) which identified strong Māori interest in library and information services within six dominant themes: intellectual access; information literacy; interrelationships between youth literacy, libraries, and schools; Māori staffing within collecting institutions; development of libraries in Māori communities; and cultural and intellectual property issues. These findings echoed a 1960s report conducted by the New Zealand Library Association and evidenced a persistent Māori interest in library-centred issues. (55)

The library community's response to Te Ara Tika Guiding Voices has included a renewable five-year plan focused on the National Library's service to Māori, Te Kaupapa Mahi Tahi - A Plan for Partnership (2001). It also includes the Manukau Libraries' Te Ao Marama (2002), a Māori service strategy from one of the country's largest public libraries. In addition, a new National Library Act (2003) was passed that acknowledges Māori interests in library collections and services; it explicitly references Mātauranga Māori (Māori knowledge), and has established the Library and Information Advisory Commission Ngā Kaiwhakamārama i ngā Kohikohinga Kōrero (LIAC) as an advisory body on the role of library and information services in social, cultural and economic life, including Mātauranga Māori. The LIANZA has since incorporated knowledge of Mātauranga Māori and the Treaty of Waitangi as essential components for professional education within the library and information sector (Fig 4).

\section{Fig. 4 Profile: Chris Szekely}

Chris Szekely served as a lead on the Te Ara Tika Guiding Voices national research project on library and information services for Māori, and has written widely in support of improved library services for Māori and on issues related to Indigenous librarianship. On March 19, 2007 , Mr. Szekely became the first Māori Chief Librarian of the Alexander Turnbull Library, a division of the National Library of New Zealand and the country's leading heritage research library and storehouse of the nation's documentary collections. One of his first tasks is to provide leadership on a major expansion of the facility to be completed in 2011. (56) Prior to this appointment, Chris Szekely served as City Librarian at Manukau City Council heading one of the largest and fastest growing public library service regions in New Zealand. During his tenure as City Librarian, he opened several new branches, including one designed with and for Pacific Islander youth, and established a bilingual catalogue and website for the library. (57) He 
is a founding member of Te Rōpū Whakahau, the national association of Māori library and information workers, and was instrumental in the formation of the International Indigenous Librarians' Forum (IILF).

\section{Indigenous Libraries and Their Intersections}

Māori perspectives view the past and the present as a continuum: the past is taonga (knowledge/treasure) that is drawn upon to shape understandings of the present. It is a source of knowledge and a guide for ethical conduct that informs living traditions. (58) Traditional knowledge comes in many forms: it may be carried in tangible objects such as carvings or wall panels; it may be textual and inscribed in writings and archival documents and carried in other modes of transmission. It is transmitted through habits and customs as well as by Elders, sometimes viewed as the living libraries of their communities: carriers of knowledge of traditional governance, science, technology, philosophy, values, healing, and history. This type of knowledge is often largely undocumented and Indigenous peoples are (re)designing structures such as libraries-archives-museums for its preservation and transmission. Manifesting a characteristically wholistic approach to knowledge, some Indigenous practitioners decline the professional distinctions between libraries, archives and museums, in favour of an approach that views spatial-temporal dimensions of knowledge and its transmission as part of a continuous whole. Conjoined with resource constraints and the affordances of new technologies one result of this type of approach is that Indigenous libraries may traverse the conventional institutional boundaries separating library-archive-museum and creatively integrate these institutions for Indigenous purposes. The locations of new knowledge centres may range from an eco-tourism centre to a school media centre, a cultural education centre to a post-secondary academic library, a literacy program to a treaty office, health services unit, or urban friendship centre. There is extensive variation in locale, clientele, services, and governance and with the local, regional, national and international institutions with which they intersect. (59) Increasingly Indigenous agencies utilize new media technologies to protect, preserve, and share knowledge. This requires new fluencies with the technologies that permeate many aspects of education, social and economic life, and environmental, legal, and governance issues in the $21^{\text {st }}$ century. For example, librarian Gene Joseph, Wet'suwet'en Dakehl, has developed libraries with First Nations in Canada for many years. She also manages First Nation litigation research and served 
as librarian for the Gitxsan Wet'suwet'en in the Delgamuukw and Gisday'way case in the Supreme Court of Canada. Gene Joseph reflects on her role as librarian during this landmark trial (Fig. 5).

\section{Fig 5. Profile: Gene Joseph}

"On December 11, 1997 the Supreme Court of Canada handed down its decision in the court case Delgamuukw v. British Columbia, [1997] 3 S.C.R. 1010 which affirmed the inherent meaning of aboriginal title. It was also the first court to rule that oral history or oral evidence be placed on equal footing with that given to historical documents. In 1984 two First Nations, the Wet'suwet'en and the Gitxsan, filed their statement of claim to $58,000 \mathrm{~km}^{2}$ which was divided into 133 territories with traditional ownership accorded to 71 Houses of the Gitxsan and Wet'suwet'en people.

In 1982 I had graduated from the University of British Columbia School of Library and Archival Sciences and it was an honour to me that in 1984 I was recruited by the Gitxsan and Wet'suwet'en to work on a collection of oral history materials from the elders and chiefs. I returned to my home in Hagwilget, a Wet'suwet'en village near Hazelton. There, I worked on the oral evidence with senior Gitxsan and Wet'suwet'en researchers: oral evidence was thoroughly reviewed, transcribed and translated by the chiefs and elders.

In 1986 Mass Gaak (Don Ryan) again recruited me to return to Hazelton, this time to work on the historical documents that had been collected as evidence. I continued to work through the trial. The trial ran for 374 days starting May 11, 1987 and ending February 7, 1990. The trial had 9200 exhibits with thousands more documents previously listed in numerous document lists, and 26,000 pages of transcripts. The decision was handed down on March 8, 1991. This was followed by the B.C. court of Appeal. This decision came down on June 25, 1993 and was appealed by the Gitxsan and the Wet'suwet'en to the Supreme Court of Canada, which rendered its decision on December 11, 1997.

Delgamuukw drew upon the technical skills I had learned at the Union of B.C. Indian Chief's Library, and the organizational, archival and computing skills learned at Library school. The oral recordings needed to be preserved and treated as archival as they recorded people who were in ill health or quite elderly. Their knowledge was invaluable. The case started just as personal computers began to be introduced into office environments, which in turn required the 
development of new software programs, database structures and the incorporation of continually developing and advancing hardware and software. The Delgamuukw Gisday'way case was one of the first court rooms in Canada to use personal computers by the court and counsel.

Historical documents had been collected from various archives in Canada, England and the United States. There were numerous scientists from various fields: archaeologists, anthropologists, linguists, historians, geographers, and genealogists gave evidence and presented documents. Therefore the language, classification and headings covered many streams of knowledge, both Western and Indigenous. Litigation support as well drew upon court requirements, counsel's needs and court reporters which were in the throes of moving from the traditional hard copy to an electronic court room.

Most of all, the trial drew upon the knowledge of the traditional systems, history and culture that I had learned from my family, and then from the elders and chiefs with whom I worked among the Gitxsan and Wet'suwet'en people. While I did not speak the language, I was constantly surrounded and worked with sound and video recordings, translators and linguists who were for the first time having to spell personal, place and spiritual names. We worked closely with the cartographer as he recorded these names onto the new maps of the territories, continually cross checking with the chiefs, elders and researchers. The map was named "The map that roared" by the court.

\section{KEY ISSUES IN INDIGENOUS LIBRARIANSHIP}

While practice and location vary, a focus of Indigenous librarianship is to provide culturally relevant information services and collections for Indigenous communities, organizations, and individuals, as well as to apply Indigenous philosophies and values to professional practice and education. The complex information requirements of Indigenous communities that may range from the maintenance and revitalization of Indigenous cultures and languages, to self governance, to rights and title claims, stewardship of traditional territories and resources, preservation of traditional knowledge systems, to municipal record keeping and standards, and a range of social, economic and educational uses calls for layered services. Indigenous-controlled libraries in Indigenous communities may be part of a web of information service provision that extends to networks of rural, urban, academic, legal, and special libraries, archives and other institutions. All of these sites offer potential arenas for the development of 
sound practice, theory, scholarship and methodology within Indigenous librarianship.

Several overarching themes that recur in practice and in the literature have been selected as key issues for Indigenous librarianship under the umbrella categories of library development, access, and cultural and intellectual property. The development of Indigenous-controlled libraries and other forms of Indigenous memory institutions is fundamental for Indigenous cultural and intellectual sovereignty. Social justice demands that Indigenous people gain equitable access to public institutions and the resources within those institutions. Equitable access includes a range of considerations including the resolution of jurisdictional barriers, the provision of culturally appropriate and relevant collections and services, and the development of meaningful knowledge organization tools; these may be bilingual or multilingual depending on the locale and clientele. Public institutions have a responsibility to staff their services with a diverse staff that represents the clientele being served and to explore innovative measures to ensure diversity. Prerequisites to the provision of equitable access include the basic infrastructure and skills to utilize library services and collections, such as Internet access, telecommunications, and multiple literacies. Literacy forms pathways composed of skills and knowledge that facilitate various levels of access to the resources offered by libraries and is therefore a fundamental issue for Indigenous librarianship. The protection of and protocols for care and management of Indigenous cultural and intellectual property (ICIP) guide the design of appropriate services, and collections and inform standards of professional ethics; virtual repatriation, an emergent area within the field may be included within this purview.

\section{Indigenous Libraries}

Against the odds Indigenous libraries endure and continue to grow. Although diverse in form, size, purpose, and location, Indigenous libraries share many similar challenges: they often compete for funds with basic services, such as roads, utilities and more urgent priorities on reserve and may be staffed by non-degreed personnel with little training. (60) Perennial funding challenges contribute to high staff turnover, inadequate facilities, and a lack of collections and technology. Indigenous communities in remote areas also face transportation and communications challenges. These barriers to the development of Indigenous libraries have remained much the same over time, however, the priorities are changing due to the ubiquity of 
information and communication technologies (ICTs) in a global networked world. ICTs present the added challenges of an ever-changing technical environment that requires the acquisition and maintenance of hardware and software, the skills sets to utilize them, and broadband access. Even if funds are available, Internet connectivity may be inadequate in many locations, and particularly remote locations may discourage the recruitment and retention of qualified staff.

\section{The Digital Divide}

ICTs have been defined as "a diverse set of technological tools and resources used to communicate, and to create, disseminate, store, and manage information." (62) The term digital divide refers to the gap between ICT 'haves' and 'have-nots'. It encompasses issues, such as IT infrastructure and access to communications technologies, use and barriers to use, and the critical role of ICT skills and literacy in an information society. From Indigenous perspectives, ICTs can support the revitalization culture and language, and serve as knowledge and communication building blocks in many areas ranging from education to health, and economic development to environmental protection. (63) They enable access to the global web of information, and perhaps more importantly they provide means by which to participate in local and distributed communities of interest. As authorial tools ICTs have the potential to create and distribute Indigenous perspectives in order to counter some of the ubiquitous stereotypes and misrepresentations, to shape attitudes and to change the ways in which history is understood. National information policy in Canada and the United States aims to provide affordable access to the Internet and to the skills required to use it. However, the National Telecommunications Information Administration (NTIA) in the United States reported that only 9\% of Native Americans in rural areas have home Internet access and that access tends to be through schools or libraries. (64) In Canada, the BC First Nations Technology Council research shows that in one-third of First Nations communities $75 \%$ of the homes are without Internet access, and in almost $20 \%$ of BC First Nations communities there are homes without basic telephone service. (65) In Canada, the Community Access Program (CAP) was one of the primary federal connectivity programs that supported Aboriginal communities for technology access and equipment, however federal funding for CAP ended in 2012. (65a) The digital divide, the ICT 
gap in access, services and skills continues to exist for Aboriginal communities and individuals.

Jean Whitehorse, a Navajo member of the Towering House clan and Born for Bitter Water clan, is making a difference. As a training and outreach coordinator for the New Mexico State Library, Whitehorse conducts IT training for tribal members in libraries and Navajo chapter houses in New Mexico. Exclaiming, "Get ready! The world is going to change with or without you!" her advocacy has resulted in the hiring of more Native American trainers and in a new internship program for tribal college students working as ICT trainers with the tribes. Whitehorse believes that as tribal members gain new digital literacy skills, the youth -- the next generation of leaders -- will be encouraged to explore the benefits and challenges of the digital world. In Digital Diné, Whitehorse draws an analogy between the artistry and expertise involved in weaving a Navajo rug and with that of weaving technology education for the nations (Fig. 6). (66)

\section{Fig. 6 Profile: Jean Whitehorse. Cyber Sovereignty: Digital Diné}

\begin{tabular}{ll}
\hline * Navajo weavers & NM State legislatures supporting Senator Tsosie \\
* Raw material in the wool & State funding and grants \\
* Tools: shears/combs/spindle/batten & Infrastructure, planning \& program development \\
* Loom & Networking \\
* Wash the wool & Outreach to the chapters \& tribal leaders \\
$*$ Card the wool & Collaborating with the Gates Foundation \\
$*$ Dye the wool & Collaborating with Navajo Community Development \\
$*$ Spinning, grandma can teach you & Technology support and computer training \\
$*$ Design and Pattern & Training evaluations
\end{tabular}

This type of multidimensional model of ICT access underlines the many threads that must be woven together to create an effective Indigenous IT strategy including: political support at local community, state, and national levels; funding and grants; relevance to community interests; culturally-based evaluation and training; social networking; and technical and soft skills. 


\section{Universal Access: An Elusive Principle}

Librarians have long upheld the principle of universal access to libraries because as the UNESCO Public Library Manifesto states, "The public library, the local gateway to knowledge, provides a basic condition for lifelong learning, independent decision-making and cultural development of the individual and social groups." (67) However, universal access to the public library is not a reality for Indigenous people in North America although it is a cornerstone of national educational and information policy in the United States and Canada. Even for Indigenous people who do "technically" live inside a library services catchment area, there continue to be many visible and invisible barriers presented through library practices, collections, and services. Many public institutions are seeking to improve their services for Indigenous people, after all, Indigenous people are community members in urban centres as well as in rural communities. Indigenous students, teachers and faculty members populate the schools and academic institutions, and are savvy social media users within the ever-expanding circles of the digital communities and economies. (68)

\section{Indigenous Approaches to Literacy}

From Indigenous perspectives the notion of literacy is conceptualized as being multidimensional and may extend from an ability to read the land to an ability to read text to the ability to use digital technologies. It includes the range of skills and knowledge required to read and interpret meanings - both explicit and implicit - and to become the authors of new meaning. Indigenous approaches to literacy seek to build bridges from existing knowledge and skills to other literacies in ways that are congruent with Indigenous cultural identity, languages and values. They are centered on local issues at the same time as they connect with an awareness of the global world. The legacies of cultural and language disruption left by colonial education systems and education designed for assimilation are integral to understandings of Aboriginal literacy education. (69) Low text literacy levels are frequently a challenge in some Indigenous communities. In Canada, the rate of illiteracy on-reserve is almost two times the rate of the offreserve Aboriginal population and three times that of the general Canadian population. (70) Within Indigenous contexts, it is important to acknowledge familial and social networks of authority and various types of literacy. Although often place based they also interconnect with 
an awareness of global issues. The relationships between ideas and knowledge, social practices and responsibilities are considered to be important. (71) English may be a second language for some learners, and for some learners Aboriginal English is the dialect used in the home, not mainstream English. Successful literacy strategies therefore incorporate programming designed for specific cultural contexts and clienteles to develop the range of literacy skills required to succeed in formal education, and to succeed in integrating Indigenous pedagogies into twentyfirst century literacy education (Fig. 7).

\section{Fig. 7 Profile: Loriene Roy}

Loriene Roy is Anishinabe, an enrolled member of the Minnesota Chippewa Tribe, White Earth Reservation, and a Professor at the University of Texas at Austin School of Information since 1987. Dr. Roy has devoted her career to improving literacy and instruction services for Native youth, advocating for library services for and by Native communities, and supporting the education of American Indian librarians. Guided by Indigenous protocols and Anishinabe teachings in her teaching and writing, Dr. Roy is a respected and visible advocate for Indigenous perspectives on national literacy and library issues in the United States, and has been an active participant in international Indigenous librarianship gatherings, serving on committees that organized the first and second IILF in 1999 and 2001. In 2007, Dr. Roy became the first American Indian president of the American Library Association, a role she filled with the same spirit and vision that she brought to her presidency of the American Indian Library Association in 1997-1998. In addition to her national and international leadership, she has served as the director of the Native American youth reading club program, "If I Can Read, I Can Do Anything" since its founding in 1999; established the "Honoring Generations" scholarship program for tribal librarians at University of Texas at Austin; assisted tribal schools with developing culturally responsive curriculum; created online resources for tribal college students; and inspired successive generations of American Indian librarians and students. (72-73) 


\section{Indigenous knowledge organization}

The dominant North American classification and subject heading systems, the Dewey Decimal Classification and the Library of Congress systems, are not adept at representing Indigenous peoples and topics. (73a) These types of knowledge organization systems are shaped by culture and they reflect worldview through the selection of terminology, concepts, and the ways they show or do not show relationships. (74) The literature documents ways in which the mainstream systems tend to marginalize, omit, or misrepresent Indigenous topics. These types of inaccuracies occur through historicization, lack of specificity, lack of relevance, lack of recognition of sovereign nations and the omission of the historical realities of colonization. (7576) Cataloging practice for Indigenous topcs must recognize the names, relationships, places, histories, and concepts used by Indigenous peoples. If Indigenous perspectives are not incorporated into knowledge organization tools, it creates another barrier to access for Indigenous peoples at the same time as perpetuating inaccurate and culturally inappropriate representation for the general public. From Indigenous perspectives, intellectual access to public collections in libraries, archives, and museums is important for educational and informational purposes, for claims research, genealogy, and the revitalization of languages, traditions, histories. (77) The dominant classification and subject heading systems are now used on a global scale, and while this enables unprecedented sharing of knowledge, it also has unprecedented power to marginalize Indigenous knowledge domains and to establish the cultural perspectives of mainstream North America as a global norm. (78) Ambitious national Indigenous thesaurus projects have been undertaken in both Australia and New Zealand to provide more balanced representation and access: Ngā Ūpoko Tukutuku the Māori subject headings thesaurus provides access to the Māori body of knowledge held in public institutions for Māori people. (79) The Australian Aboriginal and Torres Strait Islander Thesaurus aims to improve access to Aboriginal and Torres Strait Islander materials as "[i]t is important that the Indigenous voices of Australia are heard and felt through proper representation in catalogues." (80) International bodies, such as, the United Nations (UN) and the International Federation of Library Associations and Institutions (IFLA) assert the importance of preserving Indigenous knowledge and protecting the individual and collective rights of Indigenous people. However, adequate representation of Indigenous materials remains an unmet challenge for libraries as institutions, for knowledge 
organization theory and practice, and for the underlying assumptions and methodologies underlying the field.

\section{Indigenous Cultural and Intellectual Property}

The concept Indigenous cultural and intellectual property (ICIP) refers to past, present, and future tangible and intangible expressions of Indigenous heritage. These expressions exist within a body of cultural practices, knowledge systems and resources which serve to define cultural identity. (81) The results of a global study of Indigenous heritage led by Professor Erica-Irene Daes, Chairperson of the UN Working Group on Indigenous Populations, is widely cited as a standard in the area of Indigenous heritage (82). It is informed by the Declaration on the Rights of Indigenous Peoples statement which was adopted by the UN General Assembly on September 13, 2007. One of the most comprehensive statements on the individual and collective rights of Indigenous people, the Declaration states, "Indigenous peoples have the right to practice and revitalize their cultural traditions and customs. This includes the right to maintain, protect and develop the past, present and future manifestations of their cultures ...taken without their free and informed consent or in violation of their laws, traditions and customs." (83) When knowledge is removed from Indigenous communities and the systems are disrupted, there is a community loss of control over ways in which knowledge is represented and used. Some Indigenous legal concepts, such as, the notion of collective rights, do not easily fit into existing legal frameworks. Public institutions, such as libraries, archives and museums that hold Indigenous materials face a range of ICIP issues, such as, the retrospective identification of heritage materials; identification of the community of origin; the determination of copyright and ownership; ascertaining cultural restrictions on access. (84) Because existing copyright law and intellectual property law do not wholly protect ICIP, libraries may not fully understand the concerns of the Indigenous originators or clientele. Protocols have been developed as guidelines for institutions and organization to use in their interactions with Indigenous people and Indigenous materials.

\section{Indigenous Protocols for Libraries}

Indigenous protocols are seen as a bridge between Indigenous customary law and 
existing legal instruments. Protocols guide practice, and are localized in order to reflect the approaches of specific communities and the contexts of each institution's mission and collections. (85) The Aboriginal and Torres Strait Islander Library and Information Resource Network (ATSILIRN) Protocols are considered to be a leading guide for libraries. They serve as a compass for discussion, policy and practice related to the care of Indigenous materials, and development of relationships between Indigenous communities and individuals, and institutions. First published in 1995, the Protocols were revised in 2005 as living documents that are continuously updated. (86) Some of the primary concerns regarding information issues from Indigenous perspectives are governance and policy, education and training, and increased Indigenous employment and staffing. (87) In addition there are concerns regarding community ownership and rights management, guidelines for access to sensitive or sacred knowledge, and ownership of oral traditions and songs. The library sector is just beginning to engage with the ethical, legal and educational implications relating to Indigenous information services and access to Indigenous materials held by public institutions.

\section{Virtual Repatriation and Digitization Issues}

Indigenous communities have had their knowledge systems disrupted in many ways. One significant outcome is that collecting institutions, such as museums, libraries, and archives throughout the world hold large collections of materials collected from, or of significance to, Indigenous people. Virtual repatriation is the process by which digital copies of objects, recordings, images, and documents are returned to the originating Indigenous community. In some cases virtual repatriation partnerships exist between Indigenous groups and collecting institutions, such as the Smithsonian National Museum of the American Indian (NMAI) Spiral of Knowledge project. In other cases, Indigenous communities repatriate digital copies from collecting institutions or churches, or from individual collectors such as anthropologists, missionaries and others. The returned digital materials gradually amass to form local Indigenous knowledge bases which in them selves may present significant IT issues and ethical and knowledge organization challenges for a community. (88) Frequently multidisciplinary in scope with diverse types of content and file formats, these knowledge bases use software and hardware that are vulnerable to change. Systematic planning for data migration plan, attention 
to standards compliance, and consideration of sustainability, interoperability and portability issues are therefore required at the community level. Intellectual property and copyright guidelines, and digital rights management become increasingly important in these types of environments where the boundaries of collecting institutions are coalescing and technologies are converging. Mainstream collecting institutions meet their own ownership and access requirements in order to repatriate materials to communities, and Indigenous communities then may face ongoing ownership and access issues related to both the returned (historic) materials and to contemporary materials. Communities and institutions may face a range of ICIP considerations, including different kinds rights for different types of knowledge and material formats; considerations for individual viewing, public viewing, and reproduction of materials by Indigenous people or external groups; and considerations regarding community members adding their own annotations to shared databases. The rights management systems utilized must satisfy Indigenous customary approaches, as well as national laws and institutional regulations. Dr.

Martin Nakata suggests that coordinated approaches at the community level, the state level, or possibly national level may be beneficial as the number of knowledge bases and amount of content can only be expected to increase over time both within and among Indigenous communities. The complexities of these virtual repatriation processes, and related digitization issues, are beginning to constitute a specialist area of practice. (89)

\section{RESEARCH IN INDIGENOUS LIBRARIANSHIP}

Indigenous scholars are asking new questions of research, and creating an emergent scholarship that speaks to Indigenous interests in reclaiming languages, histories and knowledge, and creating new solutions to address the negative impacts of colonialism. (90) These processes require (re)conceptualizing research as transformative practice: capable of transforming the world and capable of transforming itself. Indigenous research methodology offers expanded systems of knowledge and ways of knowing that hold potential for sustainable research practices with global applicability in the twenty-first century.

Practitioners of Indigenous librarianship are positioned to take up the new methodologies of Indigenous theorists to inform research practice: there is a need for empirical, theoretical, evaluation, and policy research in Indigenous librarianship. In 1992, Dr. Cheryl Metoyer-Duran 
observed a lack of baseline data needed to conduct the research required to plan, develop, implement and evaluate services in tribal communities. "At present, there is no comprehensive study which considers the definition of tribal libraries, their location, description of resources and services, staffing or clientele.” (91). This still holds true in 2008 and continues to impede further development of planning, preservation, and the dissemination and evaluation of services and collections.

The key issues for Indigenous librarianship highlighted in this entry suggest a range of areas for future research. Areas of applied research could examine sound practices in Indigenous library development, Indigenous management of Indigenous digital libraries, local and national information policy, Indigenous literacy education, Indigenous cultural and intellectual property in public collections, Indigenous knowledge organization, professional ethics and professional fluencies within Indigenous and general library contexts. There is a need for application of social and critical theory within information studies, and Indigenous theoretical frameworks within library and information science. Linda Tuhiwai Smith's work on decolonizing methodologies could be used to provide a map of the terrain of research relationships: some research will be undertaken solely by Indigenous researchers in Indigenous communities, other types of research will be controlled by Indigenous people with outside partners, and still others will constitute a wide range of collaborative research partnerships with Indigenous people and others. (92) A fundamental challenge for the development of a research program and for informed practice is the professional education of Indigenous librarians and curriculum development for Indigenous librarianship.

\section{EDUCATION FOR INDIGENOUS LIBRARIANSHIP}

There is continues to be little Indigenous curriculum content within the professional programs. Kelly Webster, past president of the American Indian Library Association and a member of the Oneida Tribe of Indians of Wisconsin, recalls her experience in library school.

"I went to library school in the mid-1990s, and like most other students I did not hear a word about library services to American Indians in my classes, meet another Native person in the program, or encounter anything in my assigned readings on the topic" 
Employment and education of Indigenous people across the library and information sector is repeatedly cited as a high priority in the United States, Canada, Aotearoa/New Zealand and Australia. However, there has been limited success at recruitment and relevant curriculum development. The Association for Library and Information Science Education (ALISE) statistics on ALA accredited programs in the United States and Canada (2004) show full-time American Indian LIS faculty represented six positions $(0.8 \%)$ of the faculty in 51 schools. (94) In 20022003, only 26 American Indian graduates were awarded LIS degrees out of a total of 7284 graduates; there were no American Indian doctoral graduates. (95) Part of the recruitment challenge hinges on the development of culturally relevant and responsive curriculum. The Knowledge River program at the School of Information Resources and Library Science (SIRLS), University of Arizona; the University of New Mexico, INLP; and Honoring Generations at the University of Texas at Austin Information School are promising Indigenous initiatives in education and recruitment of Indigenous people. (96-98) The LIANZA statement of required skills and professional knowledge includes awareness of Indigenous knowledge paradigms described in sufficient detail to guide to curriculum development by education providers. (99)

There is a need to develop relevant $21^{\text {st }}$ century library school curriculum to support both tribal librarians and librarians in public institutions. Tribal librarians develop and deliver Indigenous library and information services; design and manage Indigenous memory institutions; facilitate repatriation efforts; and negotiate the complex relationships required to build alliances. At the same time, the broader profession and collecting institutions, require education to address widespread issues of ignorance and misunderstandings that are a legacy of past educational failures. One example of staff professional development is modeled by the University of Queensland where Indigenous and non-Indigenous library staff have partnered on developing a staff education program about Indigenous issues and histories. This occurred within an organizational climate that has a Senate-approved mandate to improve Indigenous education by challenging preconceived ideas of knowledge creation, dissemination, and recognition. (100) 


\section{PROFESSIONAL ASSOCIATIONS}

The leadership of Indigenous educators and information professionals have guided the field: from the seminal work of the National Indian Education Association in partnership with the American Library Association that produced the Goals for Indian Library and Information Service (1973) to the formation of the International Indigenous Librarians' Forum (IILF) in 1999. The following section highlights selected key Indigenous library and information professional associations.

The IILF was formed in 1999 for Indigenous library, archives and information workers to share experiences and to discuss common issues and concerns. The IILF meets every two years and publishes conference proceedings on an irregular basis. The first forum was convened by the Māori in Auckland Aotearoa/New Zealand in November 1999. Subsequent forums have been hosted by local Indigenous groups in Jokmokk, Sweden 2001; Santa Fe, New Mexico 2003; Regina, Saskatchewan 2005; Brisbane Australia 2007; Otaki in Aotearoa/New Zealand 2009; Karasjok, Norway 2011; Bellingham, Washington 2013; Winnipeg, Manitoba 2015.

The American Indian Library Association (AILA), founded in 1979 as a result of the 1978 White House Pre-Conference, has a mandate to improve library services to American Indians and Alaska Natives in school, public, and research libraries, both on and off-reservation, and to disseminate information about American Indian and Alaska Native library issues. AILA holds meetings twice a year in conjunction with the American Library Association, runs an email list that networks American Indian librarians and librarians serving American Indian communities, publishes a quarterly newsletter, and formed a classification and subject access committee to inform culturally appropriate subject representation practice.

The Aboriginal \& Torres Strait Islander Library \& Information Resource Network (ATSILIRN) was established in 1993 to provide an information network and support for Aboriginal and Torres Strait Islander peoples working in libraries. The organization also includes members and institutions whose work addresses the information needs of Australian Indigenous peoples. ATSILIRN holds annual conferences and has participated in the development of protocols for libraries and archives serving Aboriginal and Torres Strait Islanders and the compilation of the Aboriginal and Torres Strait Islander Thesaurus.

In 1992, Māori library workers established a professional association, Te Rōpū 
Whakahau (TRW, the Māori Library \& Information Workers’ Association). Its goals are to provide cultural and professional support to Māori working in libraries, and to create a forum for Māori voices to inform policies and practices relating to the care of Māori material in libraries and archives. The TRW publishes a regular newsletter, makes policy submissions, participates in research projects, organizes hui (gatherings/conferences), and produces publications related to Māori library issues.

In addition, there are numerous professional associations at the local, state/provincial, and national levels within the United States, Canada, Australia and Aotearoa/New Zealand, that are committed to the development of Indigenous library and information services, and educating the general population about Indigenous issues, histories and diverse approaches to knowledge and ways of knowing. At the international level, a proposal to form a Special Interest Group (SIG) on Indigenous knowledge was submitted to the International Federation of Libraries and Institutions Association (IFLA) at its annual conference in Quebec City (2008), and the IFLA SIG on Indigenous Matters was formally established in December 2008.

\section{CONCLUSION}

In the United States, Canada, Australia, Aotearoa/New Zealand Indigenous librarianship is located within policy environments of Indigenous self-governance and national reconciliation. Two clear implications for librarianship are: (1) Indigenous information demands will continue to grow exponentially due to expanding Indigenous self-governance activities and the exigencies of demographics and (2) Indigenous library and information services can only succeed under the direction of Indigenous nations, or in ethical partnerships between Indigenous and nonIndigenous partners. (101) The development of Indigenous libraries and information services is key for cultural and language revitalization and maintenance, and for social, economic and educational interests of Indigenous communities and individuals. At the same time rapidly growing Indigenous youth populations can be expected to increase demands for relevant programs, innovative education, and bridging programs from public institutions. (102) Equitable access to public institutions and infrastructure are required to avoid entrenching systemic twotiered systems that will further marginalize an increasingly large proportion of national populations.

The scholarship of Indigenous librarianship has important contributions to make to 
library and information science as a discipline that speaks to real-world issues in local and global contexts. It has the potential to apply Indigenous knowledge to shape the theory and practice of the broader profession, including curriculum development and research in library and information science faculties. As Indigenous librarianship serves Indigenous interests, it is also serves the education of all learners who are citizens of countries where Indigenous peoples are the First Peoples.

\section{ACKNOWLEDGEMENTS}

Olivia Robinson, Senior Policy and Project Officer, Indigenous Library Services. State Library of Queensland, Australia.

Amanda Simard, Library Specialist, Assembly of Manitoba Chiefs, Manitoba.

Wendy Sinclair Sparvier, Head, Albert Community Branch, Regina Saskatchewan.

Jean Whitehorse, Navajo member of the Towering House clan and Born for Bitter Water clan.

Training and Outreach Librarian, New Mexico State Library.

$\underline{X}$ wi7xwa Library Staff: Eleanore Wellwood, Library Assistant; Jenna Walsh, Graduate

Academic Assistant; Kim Lawson, Reference Librarian; Linda Allen, Library Assistant.

\section{AUTHORS}

Kathleen T. Burns, Mixed-blood Nlaka'pamux. Archivist, Beinecke Rare Book and Manuscript Library, Yale University; American Indian Library Association; Society of American Archivists.

Ann Doyle, Librarian, First Nations House of Learning, X Xwi7 $\underline{x} w a$ Library, University of British Columbia; Canadian Library Association, Library and Information Needs of Native Peoples Interest Group, British Columbia Library Association, First Nations Interest Group.

Gene Joseph, Wet'suwet'en Dakehl. Librarian, Environmental Aboriginal Guardianship through Law and Education (EAGLE); British Columbia Library Association, First Nations Interest Group.

Allison Boucher Krebs, Anishinaabe, member Sault Ste. Marie Tribe of the Chippewa Indians. M.L.S. Knowledge River Scholar, University of Arizona (2008); Native American Roundtable Steering Committee of the Society of American Archivists; Member of the Board of Directors, Michigan Indian Education Council.

* We note with sadness the passing of Allison Boucher Krebs on January 26, 2013. 


\section{REFERENCES}

(1) Nakata, M.; Byrne, A.; Nakata, V.; Gardiner, G. Indigenous knowledge, the library and information service sector, and protocols. In Australian Indigenous Knowledge and Libraries;

Nakata, M., Langton, M., Eds.; Australian Academic \& Research Libraries: Canberra, Australia, 2005; 9-24.

(2) Patterson, L. International issues. In Library Services to Indigenous Populations: Viewpoints and Resources; Webster, K., Ed.; Office for Literacy and Outreach Services, American Library Association: Chicago, 2005; 24-29.

(3) Denzin, N.K.; Lincoln, Y. S.; Smith, L.T. Handbook of Critical and Indigenous Methodologies. Sage Publications: Thousand Oaks, 2008.

(4) Lawson, K.L. Precious Fragments: First Nations Materials in Archives, Libraries and Museums; M.L.I.S. thesis, University of British Columbia: Vancouver, 2004.

(5) Adams, N. Professional legacies: The significance of careers in cultural preservation. Winds of Change 2005, 20 (4), 44-48.

(6) Webster, K., Ed. Library Services to Indigenous Populations: Viewpoints and Resources; Office for Literacy and Outreach Services, American Library Association: Chicago, 2005. (7) Nakata, M.; Langton, M., Eds. Australian Indigenous Knowledge and Libraries; Australian Academic \& Research Libraries: Canberra, Australia, 2005. 216.

(8) Roy, L.; Smith, A.A. Preface. In Library Services to Indigenous Populations: Viewpoints and Resources; Webster, K., Ed.; Office for Literacy and Outreach Services, American Library Association: Chicago, 2005; v.

(9) Roy, L.; Smith, A.A. Preface. In Library Services to Indigenous Populations: Viewpoints and Resources; Webster, K., Ed.; Office for Literacy and Outreach Services, American Library Association: Chicago, 2005; vi.

(10) Smith, L.T. Twenty-five Indigenous projects. In Decolonizing Methodologies: Research and Indigenous Peoples; New York: Zed Books, 1999; 142-162.

(11) Sawchuck, J.; Ed. Identities and State Structures. Vol. 2 of Readings in Aboriginal Studies; Bearpaw Publishing: Brandon, Manitoba, 1992.

(12) Canada. Indians and Northern Affairs. Communications Branch. Words First: An Evolving Terminology Relating to Aboriginal Peoples in Canada. October 2002.

http://www.ainc-inac.gc.ca/ap/pubs/wf/wf-eng.pdf (accessed June 2008). 
(13) Baer, L.A. Protection of rights of holders of traditional knowledge, Indigenous peoples and local communities. World Libraries 2002, 12 (1), 15.

http://www.worlib.org/vol12no1/baer_v12n1.shtml (accessed June 2008).

(14) United Nations. United Nations Permanent Forum on Indigenous Peoples. Factsheet - Who are Indigenous Peoples?

http://www.un.org/esa/socdev/unpfii/documents/5session_factsheet1.pdf (accessed June 2008).

(15) Russell, L. Indigenous knowledge and archives: Accessing hidden history and

understandings. In Australian Indigenous Knowledge and Libraries; Nakata, M., Langton, M.,

Eds.; Australian Academic \& Research Libraries: Canberra, Australia, 2005; 178.

(16) United States. Census Bureau. United States Census 2000.

http://www.census.gov/main/www/cen2000.html (accessed February 2008).

(17) Roy, L. Indigenous peoples and library services in the United States. In Issues and

Initiatives in Indigenous Librarianship: Some International Perspectives; Szekely, C., Ed.; Te

Rōpū Whakahau: Auckland, NZ, 1999; 36-47.

(18) Patterson, L. History and development of libraries on American Indian reservations. In International Indigenous Librarians' Forum: Proceedings, International Indigenous Librarians'

Forum, Waipapa, University of Auckland, NZ, November 1-5, 1999; Sullivan, R., Ed.; Te Rōpū Whakahau: [Wellington, NZ], 2001; 38-43.

(19) Patterson, L. History and status of Native Americans in librarianship. Library Trends 2000, 49 (1), 182-193.

(20) Metoyer-Duran, C. Gatekeepers in Ethnolinguistic Communities; Ablex Pub. Corp.: Norwood, NJ, 1993.

(21) United States. National Commission on Libraries and Information Science. Pathways to excellence : A report on improving library and information services for Native American peoples; U.S. National Commission on Libraries and Information Science: Washington, DC, 1992.

(22) New Mexico State Library. Tribal Libraries Program Direct Grant. http://www.nmstatelibrary.org/index.php?option=com_content\&view $=$ article \&id $=85 \&$ Itemid $=6$ 28 (accessed November 2008).

(23) University of New Mexico. Indigenous Nations Library Program. About INLP. http://elibrary.unm.edu/inlp/about.php (accessed November 2008). 
(24) Montana State University. Libraries. The Tribal College Librarians Professional Development Institute. http://www.lib.montana.edu/tcli/ (accessed November 2008). (25) Streams of Language, Memory and Lifeways. 2009 National Tribal Archives, Libraries, and Museums Conference Oct 18-22, 2009 Portland, OR. http://www.tribalconference.org/index.html (accessed December 2008).

(26) Biggs, B. Bright child of Oklahoma: Lotsee Patterson and the development of America's tribal libraries. American Indian Culture and Research Journal 2000, 24 (4), 55-67.

http://aisc.metapress.com/content/e4q72xwq12668875/fulltext.pdf (accessed October 2008).

(27) Oklahoma State University. Library. Oklahoma library legends: Lotsee Patterson. http://www.library.okstate.edu/dean/jpaust/legends/people/patterson.htm (accessed December 2008).

(28) Canada. Statistics Canada. Aboriginal Peoples in Canada in 2006: Inuit, Métis and First Nations, 2006 census findings; Statistics Canada: Ottawa, 2008.

http://www12.statcan.ca/english/census06/analysis/Aboriginal/index.cfm (accessed June 2008). (30) Canada. Royal Commission on Aboriginal Peoples. Report of the Royal Commission on Aboriginal Peoples; Commission: Ottawa, 1996. http://www.ainc-inac.gc.ca/ap/pubs/sg/sgeng.asp (accessed December 2008).

(31) Canada. "Apology to Former Students of Indian Residential Schools." In House of Commons Debates (Hansard). 39th Parl., 2nd Sess. (June 11, 2008) (Online) http://www2.parl.gc.ca/HousePublications/Publication.aspx?Language=E\&Mode=1\&Parl=39\& $\mathrm{Ses}=2 \& D o c I d=3568890$ (accessed November 2008).

(32) Saskatchewan. Minister's Advisory Committee on Library Services for Aboriginal People. Information is for everyone: Final report of the Minister's Advisory Committee on Library Services for Aboriginal People; Saskatchewan Provincial Library: Regina, 2001. http://www.lib.sk.ca/staff/minAboriginal/ablib/ablibfinal.html (accessed February 2008). (33) Joseph, G.; Lawson, K. First Nations and British Columbia public libraries. Feliciter 2003, $49(5), 245-247$.

(34) Lawlor, P. Ontario's First Nations public libraries: An overview with observations. Feliciter 2003, 49 (5), 240-244.

(35) Lawlor, P. Ontario's First Nations public libraries: An overview with observations. Feliciter 2003, $49(5), 243$. 
(36) Saskatchewan. Minister's Advisory Committee on Library Services for Aboriginal People. Information is for everyone: Final report of the Minister's Advisory Committee on Library Services for Aboriginal People; Saskatchewan Provincial Library: Regina, 2001. http://www.lib.sk.ca/staff/minAboriginal/ablib/ablibfinal.html (accessed February 2008). (37) Sinclair-Sparvier, W. Improving and delivering effective library services for Aboriginal peoples in Saskatchewan: A Canadian province's approach to answering the needs of the Aboriginal community. World Libraries 2002, 12 (1), 32-45.

http://www.worlib.org/vol12no1/sinclair_v12n1.shtml (accessed December 2008). (38) Edmonton Public Library. Report of the Task Force on Library Services for Aboriginal Peoples (LSAP); Edmonton Public Library: Edmonton, Alberta, November 2005. http://www.epl.ca/ResourcesPDF/ReportOfTaskForceOnLSAPFeb2006.pdf (accessed June 2008).

(39) Blake, D.; Martin, L.; Pelletier, D. Report and Recommendations of the Consultation on Aboriginal Resources and Services; Ottawa: Library and Archives Canada, 2004. http://epe.lacbac.gc.ca/100/200/301/lac-bac/rep_consult_aboriginal-e/index.html (accessed June 2008).

(40) Edwards, B.F.R. Paper Talk: A History of Libraries, Print Culture, and Aboriginal Peoples in Canada Before 1960; Scarecrow Press: Lanham, MD, 2005.

(41) Australia. Australian Bureau of Statistics. Census of Population and Housing; Australian Bureau of Statistics: Canberra, 2006.

http://www.abs.gov.au/websitedbs/D3310114.nsf/Home/census (accessed October 2008).

(42) Australia. Australian Bureau of Statistics. 1301.0 - Year Book of Australia, 2004;

Australian Bureau of Statistics: Canberra, 2004.

http://www.abs.gov.au/AUSSTATS/abs@.nsf/featurearticlesbytitle/06E6409495FF5247CA256 DEA00053A04?OpenDocument (accessed June 2008).

(43) Williams, L. Issues and initiatives in Indigenous librarianship: An Australian perspective. In Issues and Initiatives in Indigenous Librarianship: Some International Perspectives; Szekely, C., Ed.; Te Rōpū Whakahau: Auckland, NZ, 1999; 13-23.

(44) Australia. Parliament of Australia. House of Representatives. Speech by the Honourable Kevin Rudd MP - Apology to Australia's Indigenous peoples. Wednesday 13 February 2008. http://www.aph.gov.au/house/Rudd_Speech.pdf (accessed February 2008).

(45) Garlick, M. Aborigines and public libraries: Nightmare or dream(ing). Australian Library 
Review 1993, 10 (2), 218-231.

(46) Taylor, S. State Library of Queensland Indigenous Library Services: Overcoming barriers and building bridges. Australian Academic \& Research Libraries 2003, 34 (4), 278-287. http://alia.org.au/publishing/aarl/34.4/full.text/taylor.html (accessed June 2008).

(46a) State Librry of Queensland. kuril-dhagun http://www.slq.qld.gov.au/resources/atsi/kuril-dhagun

(47) National and State Libraries of Australasia Consortium. National Policy Framework for Aboriginal and Torres Strait Islander Library Services and Collections; National and State Libraries Australasia, [Melbourne, Australia], 2006.

http://www.slq.qld.gov.au/_data/assets/pdf_file/0017/74141/NSLA_National_Policy_Framewo rk_for_Aboriginal_and_Torres_Strait_Islander_Library_Services_and_Collections.pdf (accessed October 2008).

(48) National and State Libraries of Australasia Consortium. NSLA Indigenous Library Services and Collections Working Group. National Policy Framework for Aboriginal and Torres Strait Islander Library Services and Collections: 2008 Initiatives: Responding to the National policy framework.

http://www.nsla.org.au/publications/papers/2008/doc/NSLA.Discussion-Paper-20080201Indigenous.Services.Initiatives.2008.doc (accessed October 2008).

(48a) National and State Libraries of Australasia (NSLA). Re Imagining Libraries. National Position statement for Aboriginal and Torres Strait Islander library services and collections. http://www.nsla.org.au/sites/www.nsla.org.au/files/publications/NSLA.Indigenous_position_stat ement_2014.pdf (accessed October 2014).

(49) Queensland. State Library of Queensland. Aboriginal People and Torres Strait Islanders:

Strategic Documents; State Library of Queensland: South Brisbane, Australia.

http://www.slq.qld.gov.au/info/ind\#strategic (accessed October 2008).

(50) Nakata, M. Evaluation of the Northern Territory Library's Libraries and Knowledge

Centres Model; Northern Territory Government: Darwin, Australia, 2006.

http://www.ntl.nt.gov.au/_data/assets/pdf_file/0018/4680/nakata_finalreport.pdf (accessed April 2008).

(51) Hunter, J. The role of information technologies in Indigenous knowledge management. In Australian Indigenous Knowledge and Libraries; Nakata, M., Langton, M., Eds.; Australian 
Academic \& Research Libraries: Canberra, Australia, 2005; 113-128.

(52) Ji, J. Sydney welcomes its first Indigenous research fellow. Sydney Alumni Magazine 2006, Summer, 8-9. http://www.usyd.edu.au/alumni/images/content/activities/magazine/2006summer/sam.pdf (accessed June 2008).

(53) Gumbula, J.N. Exploring the Gupapuyna legacy: Strategies for developing the Galiwin'ku Indigenous Knowledge Centre. In Australian Indigenous Knowledge and Libraries; Nakata, M., Langton, M., Eds.; Australian Academic \& Research Libraries: Canberra, Australia, 2005; 2528.

(53a) Te Ahukaramū Charles Royal. 'Papatūānuku - the land - Whenua - the placenta'. In Te Ara - the Encyclopedia of New Zealand, updated 22-Sep-12. p.4 http://www.TeAra.govt.nz/en/papatuanuku-the-land/page-4

(54) Szekely, C., Ed. Issues and Initiatives in Indigenous Librarianship: Some International Perspectives; Te Rōpū Whakahau: Auckland, NZ, 1999, 48.

(55) Szekely, C. Te ara tika: Māori and libraries in New Zealand - staying the distance. World Libraries 2002, 12 (1), 46-53. http://www.worlib.org/vol12no1/szekely_v12n1.shtml (accessed June 2008).

(56) Wilson, C; Szekely, C. Upbeat: Chris Szekely Episode podcast. Radio New Zealand. Wed. May 28 2008. http://www.trumix.com/podshows/2879205 (accessed November 2008). (57) New Zealand Library Association. National Library announces appointment of Alexander Turnbull Chief Librarian. January 10, 2007.

http://www.lianza.org.nz/news/newsroom/news1168401381.html (accessed June 2008).

(58) Wikaira, J. Kaitiakitanga. The role of the Māori archivist. Archifacts 2004, Apr, 46-49.

(59) United States. National Commission on Libraries and Information Science. Pathways to excellence: A report on improving library and information services for Native American peoples; National Commission on Libraries and Information Science: Washington, DC, 1992. (60) Patterson, L. Tribal and reservation libraries. Rural Libraries 2001, 22 (1), 19-24.

(61) Patterson, L. History and development of libraries on American Indian reservations. In International Indigenous Librarians' Forum: Proceedings, International Indigenous Librarians' Forum, Waipapa, University of Auckland, NZ, November 1-5, 1999; Sullivan, R., Ed.; Te Rōpū Whakahau: [Wellington, NZ], 2001; 38-43.

(62) Blurton C.G. New directions in education. In World Communication and Information 
Report 1999-2000; Bartagnon, G., Courrier, Y., Eds. Paris, UNESCO Publishing, 1999: 46-61. http://www.unesco.org/webworld/wcir/en/pdf_report/chap2.pdf (accessed November 2008). (63) Gordon, A.C.; Dorr, J.; Gordon, M. Native American technology access: The Gates Foundation in Four Corners. The Electronic Library 2003, 21 (5), 428-434.

(64) Patterson, L. History and status of Native Americans in librarianship. Library Trends 2000, $49(1), 192$.

(65) First Nations Technology Council. Information and communications technology in B.C. First Nations communities. March 2005.

http://www.fntc.info/files/documents/Environmental_Scan_Final_Report.pdf(accessed October 2008).

(65a) Industry Canada. Youth Internships. What Happened to the Community Access Program (CAP)? April 19, 2013. http://www.ic.gc.ca/eic/site/cap-pac.nsf/eng/00023.html (accessed October 2014).

(66) Whitehorse, J. Cyber sovereignty: Digital Diné. In International Indigenous Librarians' Forum III: Closer to the Fire: Ensuring Culturally Responsive Library Practices, Santa Fe, NM, Nov 10-13, 2003; Ongley, D., Ed.; American Indian Library Association: [Norman, OK?], $2005 ; 145-146$.

(67) International Federation of Library Associations and Institutions. IFLA/UNESCO public library manifesto, 1994. http://www.ifla.org/VII/s8/unesco/eng.htm (accessed February 2008). (67a) Joseph, G.; Lawson, K. First Nations and British Columbia Public Libraries. Feliciter 2003, 5, 245-247.

(68) Webster, K. Introduction. In Library Services to Indigenous Populations: Viewpoints and Resources; Webster, K., Ed.; Office for Literacy and Outreach Services, American Library Association: Chicago, 2005; ix-x.

(69) Hare, J. To 'know papers': Aboriginal perspectives on literacy. In Portraits of Literacy Across Families, Communities and Schools: Tensions and Intersections; Anderson, J., Kendrick, M., Rogers, T., Smythe, S., Eds.; Lawrence Erlbaum Associates: Mahwah, NJ, 2005; 243-263. (70) Canada. Indian Affairs and Northern Affairs Canada. Highlights of Aboriginal conditions 1991, 1986: Demographic, social and economic characteristics; Indian Affairs and Northern Development: Ottawa, 1995. http://www.ainc-inac.gc.ca/ai/rs/pubs/sts/hilts/hilts-eng.pdf (accessed December 2008). 
(71) Hermes, M.; Uran, C. Treaties that dominate and literacy that empowers? I wish it was all in Ojibwemowin. Anthropology and Education Quarterly 2006, 37 (4), 393-398.

(72) Roy, L. To support and model Native American library services. Texas Library Journal 2000, 76 (1), 32-35. http://www.txla.org/pubs/tlj76_1/native.html (accessed February 2008).

(73) Roy, L. Dr. Roy's Web site Loriene Roy: Professor of Library and Information Science. website. http://www.ischool.utexas.edu/ loriene/ (accessed June 2008)

(73a) Simpson, S. (2005). Te ara tika - guiding words: Phase 3 research report. Wellington, NZ: Te Rōpū Whakahau. Retrieved from www.trw.org.nz/publications/Te_Ara_Tika_Guiding_Words.pdf (74) Foskett, A.C. The Subject Approach to Information, $4^{\text {th }}$ Ed.; Clive Bingley Ltd.: London, 1982.

(75) Carter, N.C. American Indians and law libraries: Acknowledging the third sovereign. Law Library Journal 2002, 94 (1), 7-26. http:/www.aallnet.org/products/pub_1lj_v94n01/200201.pdf (accessed December 2008).

(76) Moorcroft, H. The construction of silence. Australian Library Journal 1993, 42 (1), 27-32.

(77) Joseph, G. Library services to First Nations in British Columbia. BCLA Reporter 1995, 39 (4), 37.

(78) Olson, H.A. The Power to Name: Locating the Limits of Subject Representation in Libraries; Kluwer Academic Publishers: Dordrecht, The Netherlands, 2002.

(79) Simpson, S. Te ara tika: Guiding words: Ngā ingoa kaupapa Māori: Māori subject headings: Pūrongo tuatoru: Phase three research report. Te Rōpū Whakahau, in association with the National Library of New Zealand and LIANZA: Auckland, NZ, 2005. http://www.trw.org.nz/publications/Te_Ara_Tika_Guiding_Words.pdf (accessed June 2008). (80) National Library of Australia. The Aboriginal Thesaurus, First Roundtable on Library and Archives Collections and Services of Relevance to Aboriginal and Torres Strait Islander People, State Library of South Australia, Adelaide, 4 May 1995; 1.

http://www.nla.gov.au/niac/libs/thesaurus.html (accessed June 2008).

(81) Janke, T. Managing Indigenous knowledge and Indigenous cultural and intellectual property. In Australian Indigenous Knowledge and Libraries; Nakata, M., Langton, M., Eds.; Australian Academic \& Research Libraries: Canberra, Australia, 2005; 99-111.

(82) Daes, E. Discrimination against Indigenous peoples: Protection of the heritage of 
Indigenous people. Final report of the Special Rapporteur, Mrs. Erica-Irene Daes, in conformity with Subcommission resolution 1993/44 and decision 1994/105 of the Commission on Human Rights, E/CN.4/Sub.2/1995/26; Geneva: United Nations, Office of the UN High Commissioner on Human Rights, 1995.

http://www.unhchr.ch/Huridocda/Huridoca.nsf/0/c6646bc7fe89406f802566c0005cd3f0?Opendo cument (accessed June 2008).

(83) United Nations. General Assembly. United Nations Declaration on the Rights of Indigenous Peoples. Article 13.1, A/Res/61/295; [United Nations]: [New York], 2007. http://www.un.org/esa/socdev/unpfii/en/declaration.html (accessed December 2008). (84) Nakata, N.M. Indigenous digital collections. Australian Academic \& Research Libraries 2007, 38 (2), 101.

(85) Nakata, M.; Byrne, A.; Nakata, V.; Gardiner, G. Indigenous knowledge, the library and information service sector, and protocols. In Australian Indigenous Knowledge and Libraries; Nakata, M., Langton, M., Eds.; Australian Academic \& Research Libraries: Canberra, Australia, 2005; 9-24.

(86) Aboriginal and Torres Straits Islander Library Information and Resource Network Inc. ATSILIRN Protocols. http://www1.aiatsis.gov.au/atsilirn/protocols.atsilirn.asn.au/index0c51.html?option=com_frontp age \&Itemid $=1$ (accessed June 2008).

(87) Garwood-Houng, A. Protocols: Meeting the challenges of Indigenous information needs. In Australian Indigenous Knowledge and Libraries; Nakata, M., Langton, M., Eds.; Australian Academic \& Research Libraries: Canberra, Australia, 2005; 149-157.

(88) Hunter J. The role of information technologies in Indigenous knowledge management. Australian Academic \& Research Libraries 2007, 38 (2), 113-128.

(89) Nakata, N.M. Indigenous digital collections. Australian Academic \& Research Libraries 2007, 38 (2), 99-110.

(90) Smith, L.T. On tricky ground: Researching the native in the age of uncertainty. In The SAGE Handbook of Qualitative Research, 3rd Ed.; Denzin, N.K., Lincoln, Y.S., Eds.; Sage Publications: Thousand Oaks, 2005; 85-107.

(91) Metoyer-Duran, C. Native American library and information services. Government Information Quarterly 1992, 9 (3); 359. 
(92) Smith, L.T. Decolonizing Methodologies: Research and Indigenous Peoples; New York: Zed Books, 1999.

(93) Webster, K. Introduction. In Library Services to Indigenous Populations: Viewpoints and Resources; Webster, K., Ed.; Office for Literacy and Outreach Services, American Library Association: Chicago, 2005; vii.

(94) Association for Library and Information Science Education (ALISE). Table I-17: Ethnic Background of Full-time Faculty. January 1, 2004 http://ils.unc.edu/ALISE/2004/Faculty/Table\%20I-17.htm (accessed June 2008).

(95) Association for Library and Information Science Education (ALISE). Table II-3-a:Degrees and Certificates Awarded by Gender and Ethnic Origin 2002-2003. http://ils.unc.edu/ALISE/2004/Students/Table\%20II-3-a.htm (accessed June 2008). (96) Aguilar, P.L. University of New Mexico libraries’ Indigenous nations library program (INLP): Reaching out and serving the UNM American Indian community and New Mexico American Indians. College \& Research Libraries News 2006, 67 (3), 158-160.

(97) Berry, J.N. Knowledge river. Library Journal (1976). 2004, 129 (7), 55. http://www.libraryjournal.com/article/CA408335.html (accessed December 2008). (98) School of Information. University of Texas at Austin. Developing the next generation of Native librarians. Honoring Generations Home Page Web site. http://www.ischool.utexas.edu/ hg/ (accessed November 2008). (99) New Zealand Library Association Inc. LIANZA Statement: The library and information sector: core knowledge, skills and qualities. Appendix.

http://www.lianza.org.nz/registration/files/Body_of_Knowledge_Appendix_Oct08.pdf (accessed November 2008).

(100) Australian Library and Information Association. inCite 2008, 29 (7). Special Issue. Indigenous Librarianship.

(101) Metoyer-Duran, C. Native American library and information services. Government Information Quarterly 1992, 9 (3), 359-362.

(102) Townley, C.T. American Indian library service. In Advances in Librarianship. Michael H. Harris, Ed.; Academic Press: New York, 1978; 152-159. 